\title{
NUMERICAL SIMULATION OF TSUNAMI HAZARDS IN SOUTH ATLANTIC COAST: CASE OF THE CITY OF AGADIR -MOROCCO: PRELIMINARY RESULT
}

\author{
Zainab Fajri ${ }^{1, *}$, M. Outiskt ${ }^{1}$, Y. Khouyaoui ${ }^{1,}$ S. El moussaoui ${ }^{2,}$ H. El Talibi ${ }^{2}$, K. Aboumaria \\ ${ }^{1}$ Faculty of Sciences and Techniques of Tangier, Morocco- zainab.fajri@etu.uae.ac.ma \\ ${ }^{2}$ Faculty of Sciences and Techniques of Al Hoceima, Morocco \\ * Corresponding author
}

KEY WORDS: Morocco, Agadir, Tsunami, DEM, BTV, Building, Risk management.

\begin{abstract}
:
The coastal zone is a highly complex area because of its location at the interface between land and sea and as a preferred location for many forms of development. A mega tsunami from the Canary Islands will hit not only the Atlantic coasts of Morocco, but also Spain, Portugal, Great Britain and even reach US shores.

A slight earthquake or possible volcanic eruption can trigger one of the most violent natural disasters in history. Indeed, according to Steven Ward and Simon Day (2001) the west flank of the Cumbre Vieja volcano, located on the island of Palma is unstable and could, as a result of a future eruption, collapse into the ocean. It would be in the worst scenario of a huge piece of $25 \mathrm{~km}$ long, 15 wide and 1,400 meters thick that would come off, a total of 500 cubic kilometers of land and rocks. This wave could reach 50 meters of height, once arrived on the Moroccan coasts. In this study, a numerical inundation and vulnerability models are used to identify the location and nature of current and future hazards and risk on the Moroccan coast to better understand the tsunami hazard and vulnerability along the Moroccan coast. We have worked on the correction of coastlines from satellite imagery on Google Earth and the digitization of bathymetric and topographic maps, in order to create digital elevation models (DEM). We have also studied the vulnerability assessment of the buildings by using the BTV model (Building Tsunami Vulnerability) such as a combination of tsunami inundation numerical modelling, field survey data and geographic information system.
\end{abstract}

\section{INTRODUCTION}

A tsunami is a series of waves caused by mechanical action at sea or ocean. It is generally of tectonic, volcanic or gravitational origin, for example an underwater landslide generated by an earthquake. The life of Tsunamis can be described in three phases: the generation, the propagation and the inundation.

In recent years, two major tsunamis have left a deep impression on the number of victims and of the damage caused; 2004 tsunamis in Indonesia, and 2011 in the Pacific coast of Tōhoku in Japan.

Tsunami risk scenarios have been accomplished in areas affected by the 2004 event. They defined a building typology introducing 7 structural classes. This classification takes into account only the materials used for the construction of the walls (Garcin et al. 2007).

A study was about the city of Syracuse in Italy as one of the sites exposed to the destructive tsunamis generated on the escarpment of Malta. In this context, this work focuses on assessing the vulnerability of the city's housing stock to tsunamis. the Papathoma Tsunami Vulnerability Assessment Model (PTVA). For a flood level of $5 \mathrm{~m}$, a total of 2,446 buildings were inventoried. 'High' and 'very high' damage are estimated not only in the slum area, but also for most waterfront constructions on the west coast (Pagnoni, et al 2016).

A work based on a combination of numerical modeling of tsunami floods, field survey data, a geographic information system (GIS) and the building tsunami vulnerability model (BTV), proposed by Omira et al 2010 to estimate the tsunami vulnerability of the housing stock (they used a tsunami scenario compatible with that of 1755 in the city of Casablanca). The researchers concluded that Casablanca should benefit from redevelopment programs because most of the buildings are not configured to effectively reduce the risk from the tsunami. Omira et al., 2010 describe three parameters that influence the vulnerability of buildings: i) construction condition, ii) flood zone and iii) quality of coastal defense infrastructure.

El Moussaoui et al in 2017 carried out a study relating to the 1755 Lisbon tsunami. To assess the tsunami risk on the city of Asilah, specifically the building stock, a Tsunami Vulnerability Model (BTV) proposed by Omira et al, was combined with GIS tools and field survey data. In conclusion, the calculated tsunami impact at Asilah confirms that the northwest coast of Morocco is one of the dangerous coasts facing an Atlantic Ocean tsunami. Also, a high percentage of the housing stock in the Asilah flood zone $(41.6 \%)$ is very vulnerable to the impact of the tsunami, which shows that the structures are not designed to withstand the impact of the tsunami.

Numerical modeling, developed since the 1960s, is based on the programming of theoretical or mathematical models, integration of equations of motion, differential equations, etc., which are adapted to digital means. For the tsunami studies, numerical modeling makes it possible to assess the hazard and to propose credible scenarios in areas where historical data are incomplete (Roy et al., 2015a, 2015b). Tsunami modeling consists of reproducing past events or making predictions of them for others. Knowledge of the historical tsunamis that affected Morocco is insufficient to estimate the hazard. Therefore, numerical modeling is the only way to determine approximately the areas that would be flooded, the water levels and the arrival times of a tsunami (Amine et al, 2018).

\section{STUDY AREA}

The study area is part of Agadir Bay. This position gives it a role of economic relay through which all north-south flows transit and it also has a strategic role in economic and socio-cultural terms (Aouiche, 2016). 


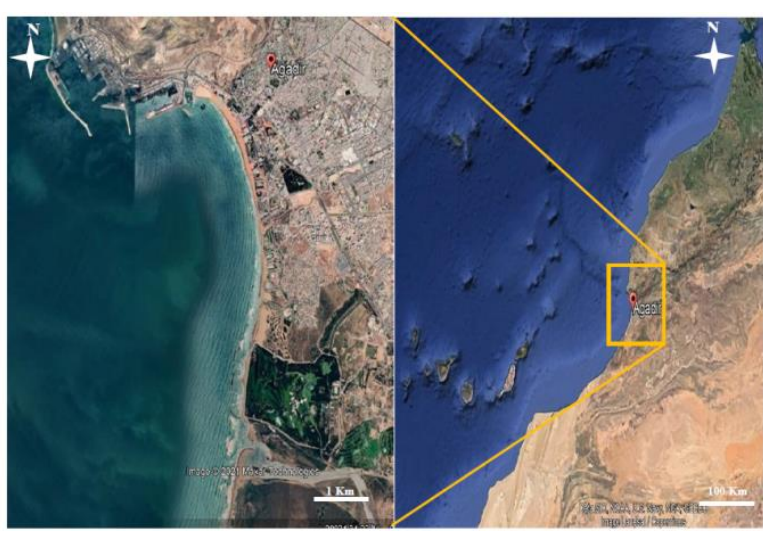

Figure1. Agadir Bay's Geographic location (Google Earth, 2021).

\section{METHODOLOGY}

Developing the tsunami simulation and tsunami damage is a multi-step process. A set of bathymetric and topographic data was generated in order to cover the region from the source of the tsunami to the target area by the inundation. The different data used in this study are presented below as well as the method used to construct the DEM:

\subsection{Bathymetric data and extraction of the grids}

The bathymetric data of the nested grids used in the simulation come from the international database GEBCO (General Bathymetric Chart of the Oceans) of resolution $R=0.0041$. The resolutions are kept using the Minimum Curvator-Surface interpolation under the Mirone software, go from 0.004 to 0.00025 . The management of nested grids, necessary to refine the resolution towards the impact zone, in order to fully understand the behavior of the wave, and therefore better prevention.

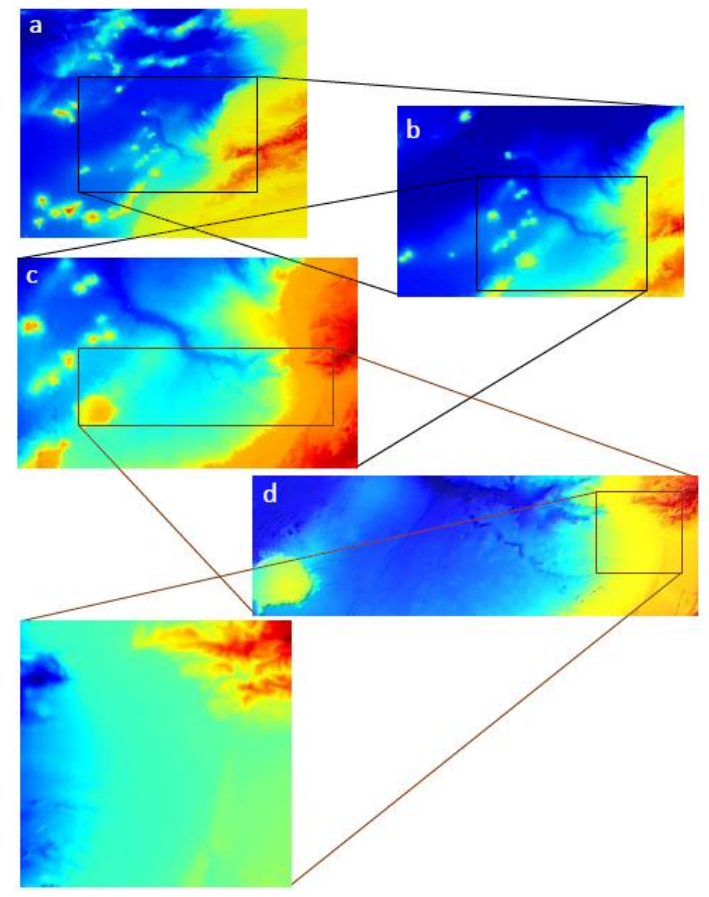

Figure2. Grids creation; a) $\mathrm{R}=0,004$ b) $\mathrm{R}=0,002$ c) $R=0,001$ d) $R=0,0005$ e) $R=0,00025$
The fourth grid $0.00025 \mathrm{DD}(25 \mathrm{~m})$, which represents our area of interest, was generated by interpolation of the bathymetric data from the marine navigation chart, from the source Marine hydrographic and oceanographic service (SHOM).

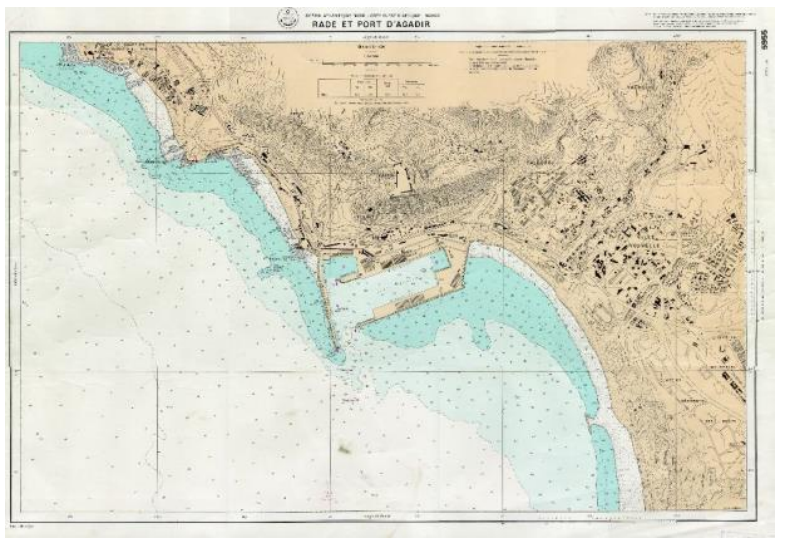

Figure3. Marine navigation chart (SHOM).

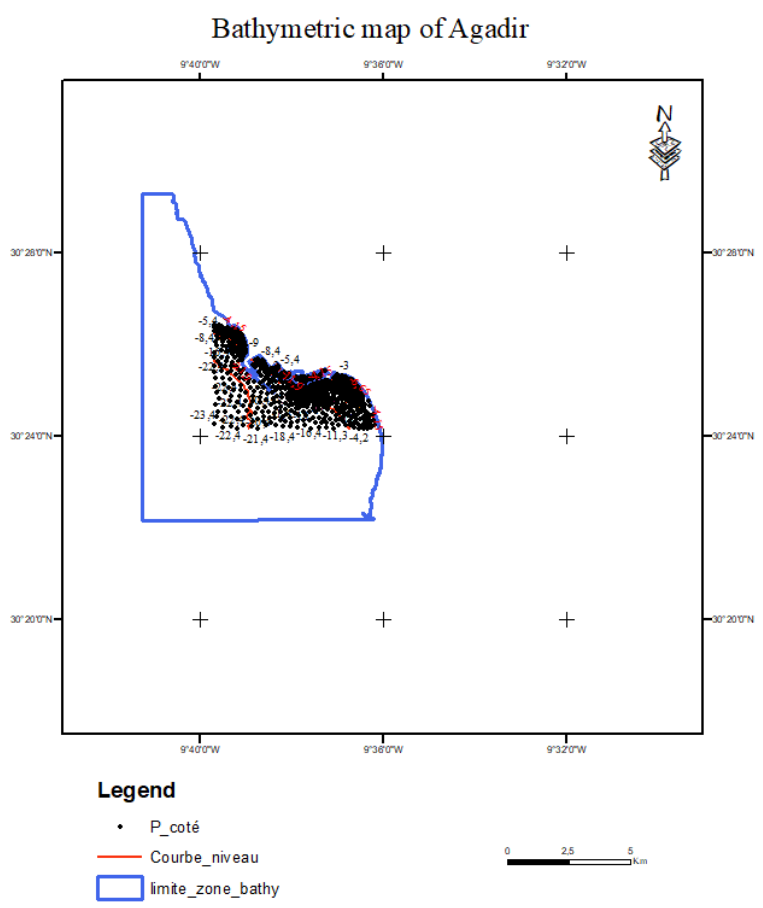

Figure4. Bathymetric data of the Agadir area digitized

\subsection{Coastline digitized}

The isohypse " $0 \mathrm{~m}$ " comes from of the coastline digitized by our team. The coastline has been digitized approximately $24 \mathrm{~km}$ in length. 


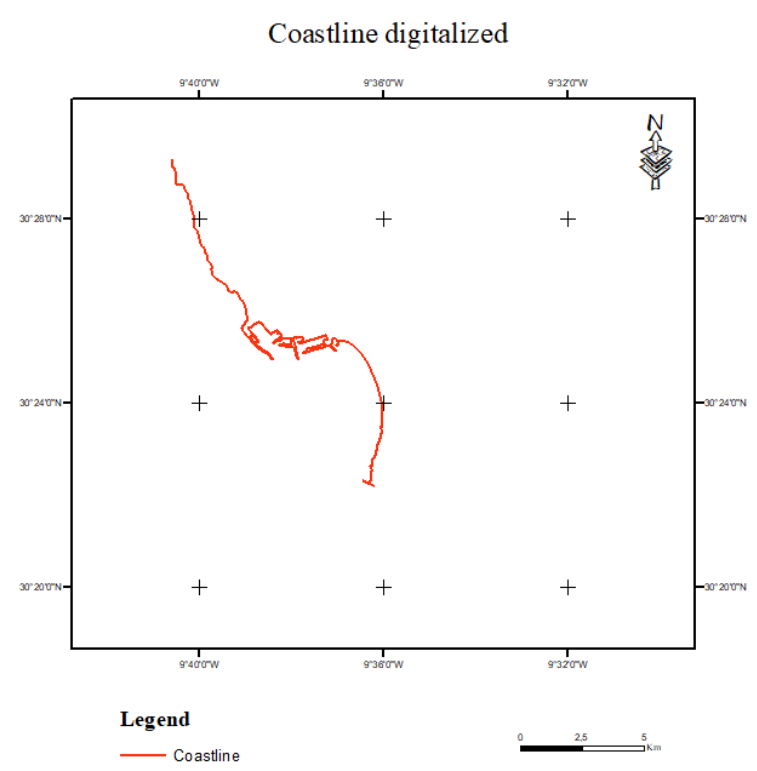

Figure5. Isohypse "0", Coastline.

\subsection{Topographic data}

Topographic data from the database ASTER GDEM V3 (Global Digital Elevation Map) with a resolution of $30 \mathrm{~m}$.

\section{RESULTS}

\subsection{Digital Elevation Model}

The DEM used in this study was produced by combining land and sea data using TOPO to RASTER interpolation, at a resolution of $30 \mathrm{~m}$.

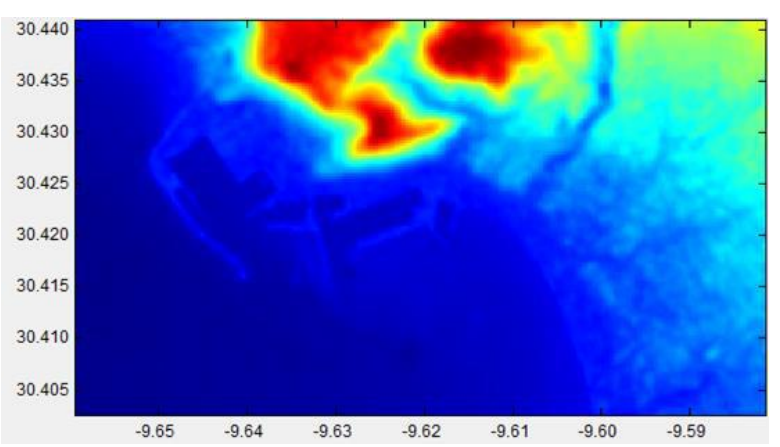

Figure6. Digital Elevation Model of Agadir bay

\subsection{Classification of buildings}

The study of the vulnerability of buildings in Agadir uses the BTV model (Building tsunami vulnerability) proposed by Omira et al (2010), this model is based on three characteristics (mentionned in the introduction):

In order to prevent and reduce the tsunamigenic risk, it was necessary to study the type of components and the number of floors, and then classify them according to the quality.

(Omira et al, 2010) established a typology of buildings specific to Morocco. This typology takes into account a large number of construction parameters:

Number of floors, type of construction materials (brick, dry stone, concrete block, etc.), supporting structure (reinforced or not), depth of foundations, roofing materials, calculated or selfconstructed structure, type of anchoring of the structure to the foundations, quality of materials used; Filling or not of the walls;
Compliance or not of the building with the Moroccan earthquake code (RPS 2000). This typology is based on the identification of criteria that can influence the resistance of a building in the face of a tsunami wave submersion. The comparison of different typologies identified by Omira et al., 2010 allowed us to identify the most relevant criteria for an assessment of the vulnerability of buildings.

The characteristics and descriptions of these types of buildings are summarized in Table 1 and Figure 7:

\begin{tabular}{|c|l|c|}
\hline $\begin{array}{c}\text { Class of } \\
\text { Buildings }\end{array}$ & Structure, materials used and quality of construction & Resistance \\
\hline A & $\begin{array}{l}\text { Three storeys and more, Designed buildings, reinforced } \\
\text { concrete construction with well-lined beams and walls and } \\
\text { good foundations (towers, Residences, Shops, Offices and } \\
\text { schools). }\end{array}$ & Good \\
\hline B & $\begin{array}{l}\text { One to third storeys. Good foundations, reinforced cement } \\
\text { beams and good architect (Villas, Detached houses) } \\
\text { Residential or commercial buildings in concrete (large } \\
\text { villas, collective buildings). }\end{array}$ & Medium \\
\hline C & $\begin{array}{l}\text { Single or second storeys, light buildings made of wood, } \\
\text { glass, clay or sheet metal. Fragile brick houses...(Medina, } \\
\text { Economic buildings, Anarchic buildings) Individual houses. }\end{array}$ & Bad \\
\hline
\end{tabular}

Table1.Construction classification along the study area
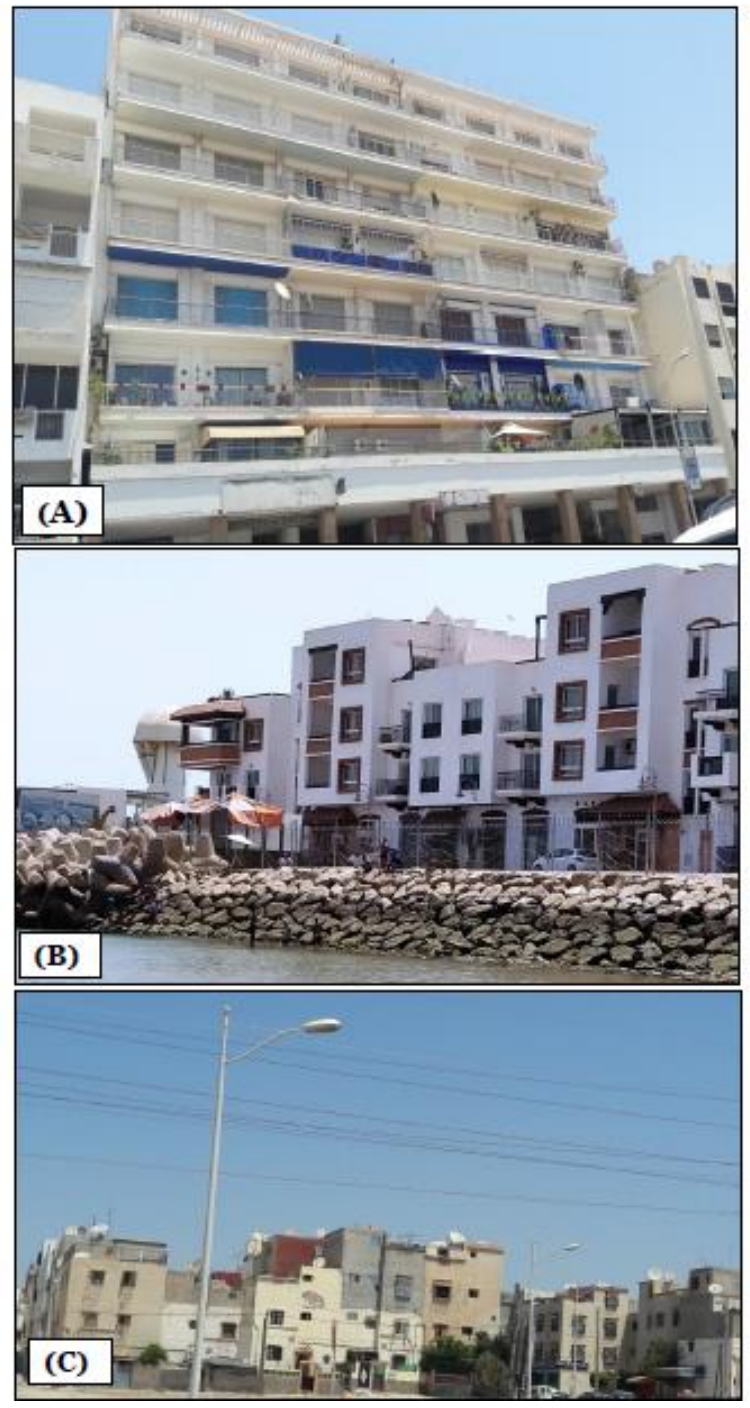

Figure7. Type of buildings in the study area 


\section{DISCUSSION}

Buildings in Agadir bay closest to the sea such as hotels, restaurants, cafes, and games areas from the palace royal in the south to the port in the north and surrounding buildings such as residences, cafes, shops and restaurants are very exposed to the risk of tsunami as most of these buildings.

The results obtained in this study with other parameters such as the proximity of the Canary Islands to the target area with the coastal topography, show that the bay of Agadir is seriously exposed to the risk of the tsunami. In comparison with the study carried out by Ward and Day in 2001, the results show that the Moroccan Atlantic coasts are not immune to the impact of this tsunami, especially Agadir, which could be subjected to huge waves. In addition, the lack of information on this likely tsunami makes comparison difficult.

In order to have good results of the Moroccan Atlantic coast to tsunamis, it is preferable to study each city separately by applying a suitable vulnerability model to Moroccan constructions; the most recommended is the BTV (Omira et al 2010). Indeed, it overcame the PTVA limitation, by providing a detailed modeling of tsunami flooding in terms of flow depth and associating it with vulnerability to tsunami.

In addition, the Building Tsunami Vulnerability (BTV) model (Omira et al. 2010) uses a different approach, compared to the PTVA model, regarding the weighting / ranking of the different factors that control tsunami vulnerability. The BTV distinguishes separately between "main criteria" and "intrinsic attributes" that influence vulnerability to tsunamis. The main criteria, which are defined and weighted independently of the test site, are i) construction condition, ii) flood zone and iii) quality of coastal defense infrastructure. The intrinsic attributes, which depend on the site studied, characterize the buildings (attributes: construction material, number of floors, state of the foundations, etc.), flooding (attribute: depth of flow) or sea barriers (attributes: construction material, dimensions ...). The main advantage of considering buildings and sea defense classes in the BTV model is the possibility of applying the methodology to large coastal areas, incorporating various types of buildings and barriers which reduce the time required for field surveys.

\section{- $\quad$ Risk managemen}

Tsunamis represent a risk which can cause loss of human life, material damage and environmental degradation. In the city of Agadir, planners, officials and environmental protection organizations must work in partnership to improve the risk management: This is based on knowledge and education about the risk, if the population is more informed about tsunamis, the number of victims could be reduced considerably.

It is recommended to avoid new construction in areas identified as exposed, to apply construction standards to new buildings.

\section{CONCLUSION}

A potential catastrophic event could occur on the island of $\mathrm{La}$ Palma if the Cumbre Vieja volcano activates, causing a landslide. A tsunami could be generated and would cause serious damage along the Moroccan Atlantic coast, in particular the city of Agadir.

The results obtained show that a high percentage of buildings in the bay of Agadir such as hotels, restaurants, cafes, and play areas, as well as the port and the residences in its surroundings, would be very vulnerable to the impact of the tsunami:
The impact of tsunamis on the population is devastating. Indeed, the BTV model allowed us to assess the risk of a tsunami.

A tsunami prevention system is recommended to limit their effects.

- Raising awareness among the population of the city of Agadir could reduce the number of victims.

- The results of this work require better risk management, the development of design standards for buildings resistant to buildings that could be built in the flooded area.

\section{REFERENCES}

Benchekroun, S., Omira, R., Baptista, M. A., El Mouraouah, A., Brahim, A. I., \& Toto, E. A. (2015). Tsunami impact and vulnerability in the harbour area of Tangier, Morocco. Geomatics, Natural Hazards and Risk, 6(8), 718-740.

Blanc, P. L. (2009). Earthquakes and tsunami in November 1755 in Morocco: a different reading of contemporaneous documentary sources. Natural Hazards and Earth System Sciences, 9(3), 725-738.

Boen, T. (2006). Yogya Earthquake 27 May 2006: Structural Damage Report. EERI.

Dominey-Howes, D., \& Papathoma, M. (2007). Validating a tsunami vulnerability assessment model (the PTVA model) using field data from the 2004 Indian Ocean tsunami. Natural Hazards, 40(1), 113-136.

El Moussaoui, S., Omira, R., Zaghloul, M. N., El Talibi, H., \& Aboumaria, K. (2017). Tsunami hazard and buildings vulnerability along the Northern Atlantic coast of Moroccothe 1755-like tsunami in Asilah test-site. Geoenvironmental Disasters, 4(1), 1-14.

Garcin, M., Desprats, J. F., Fontaine, M., Pedreros, R., Attanayake, N., Fernando, S., ... \& Poisson, B. (2008) Integrated approach for coastal hazards and risks in $\mathrm{Sr}$ Lanka. Natural Hazards and Earth System Sciences, 8(3), 577-586.

Grilli, A. R., Grilli, S. T., David, E., \& Coulet, C. (2015), Modeling of tsunami propagation in the Atlantic Ocean Basin for tsunami hazard assessment along the North Shore of Hispaniola. In The Twenty-fifth International Ocean and Polar Engineering Conference. OnePetro.

Hebil, E. (1972). Reconnaissance Hydrogeologique Du Haut Bassin Versant De L'oued Souss A Aoulouz (Maroc).

Ismail, H., Abd Wahab, A. K., Amin, M. M., Yunus, M. M. \& Sidek, F. J. (2012). A 3-tier tsunami vulnerability assessment technique for the north-west coast of Peninsular Malaysia. Natural hazards, 63(2), 549-573.

Lambert, J., \& Terrier, M. (2011). Historical tsunami database for France and its overseas territories. Natural Hazards and Earth System Sciences, 11(4), 1037-1046.

Mellas, S., Leone, F., Omira, R., Gherardi, M., Baptista, M. A., Zourarah, B., ... \& Lagahé, É. (2012). Le risque tsunamique au Maroc: modélisation et évaluation au moyen d'un premier jeu d'indicateurs d'exposition du littoral atlantique. Physio-Géo. Géographie physique et environnement, (Volume 6), 119-139. 
McGuire, M. (2006). Collaborative public management: Assessing what we know and how we know it. Public administration review, 66, 33-43.

Mhammdi, N., Medina, F., Kelletat, D., Ahmamou, M., \& Aloussi, L. (2008). Large boulders along the Rabat coast (Morocco); possible emplacement by the November, 1st, 1755 AD tsunami. Science of Tsunami Hazards, 27(1), $17-$ 30.

Omira, R., Baptista, M. A., Miranda, J. M., Toto, E., Catita, C., \& Catalao, J. (2010). Tsunami vulnerability assessment of Casablanca-Morocco using numerical modelling and GIS tools. Natural hazards, 54(1), 75-95.

Pagnoni, G., \& Tinti, S. (2016). Application and comparison of tsunami vulnerability and damage models for the town of Siracusa, Sicily, Italy. In Global Tsunami Science: Past and Future, Volume I (pp. 3795-3822). Birkhäuser, Cham.

Papadopoulos, G. A., \& Dermentzopoulos, T. (1998). A tsunami risk management pilot study in Heraklion, Crete. Natural Hazards, 18(2), 91-118.

Papathoma, M., \& Dominey-Howes, D. (2003). Tsunami vulnerability assessment and its implications for coastal hazard analysis and disaster management planning, Gulf of Corinth, Greece. Natural Hazards and Earth System Sciences, 3(6), 733-747.

Pedreros, R., Terrier, M., \& Poisson, B. (2007). Tsunamis: étude de cas au niveau de la côte antillaise française. Rapport de synthèse BRGM/RP, 55795, 77.

Ruangrassamee, A., Yanagisawa, H., Foytong, P., Lukkunaprasit, P., Koshimura, S., \& Imamura, F. (2006). Investigation of tsunami-induced damage and fragility of buildings in Thailand after the December 2004 Indian Ocean tsunami. Earthquake Spectra, 22(3_suppl), 377-401.

Saatcioglu, M., Ghobarah, A., \& Nistor, I. (2006) Performance of structures in Indonesia during the December 2004 great Sumatra earthquake and Indian Ocean tsunami. Earthquake Spectra, 22(3_suppl), 295-319. 